\title{
Alicja Witalisz \\ Anglosemantyzmy $w$ języku polskim - ze słownikiem Język a komunikacja 16, Kraków 2007, ss. 342
}

Zapożyczenia z języka angielskiego we współczesnej polszczyźnie były w ostatnich latach przedmiotem licznych artykułów i książek. Spora część $\mathrm{z}$ nich, szczególnie te publikowane $\mathrm{w}$ wydawnictwach popularnych, ma charakter normatywny ${ }^{1}$. Ich autorzy najczęściej ubolewają nad zaśmiecaniem polszczyzny. Inne mają charakter naukowy, ściśle lingwistyczny, przynoszą informacje o rzeczywistym zasięgu zjawiska oraz jego przyczynach. $\mathrm{W}$ badaniach nad zapożyczeniami leksykalnymi z języka angielskiego najbardziej zasłużyła się E. Mańczak-Wohlfeld ${ }^{2}$. Syntetyczny opis polsko-angielskich kontaktów językowych przedstawiła oraz literaturę przedmiotu zgromadziła E. Sękowska w „Poradniku Językowym”3.

Obserwując piśmiennictwo poświęcone wpływom obcym na język polski, łatwo zauważyć, że najwięcej uwagi poświęcono zapożyczeniom leksykalnym, co zresztą nie dziwi, gdyż wyrazy obcego pochodzenia najłatwiej dostrzec $w$ tekstach. Znacznie rzadziej natomiast zajmowano się

1 I piszącemu tę recenzję zdarzyło się zabierać głos w sprawie zapożyczeń $\mathrm{z}$ języka angielskiego, zob. np. H. Duda, Drajwer, recykling, hit - wyrazy angielskie we współczesnym języku polskim, „Lamus” [Gorzów Wielkopolski] 2008, nr 1 (17), s. 54-60; tenże, Język polski po komunizmie: nowomowa, demokratyzacja języka, zapożyczenia z języka angielskiego, wulgaryzacja, [w:] Język, literatura i kultura Słowian dawniej $i$ dziś - III. Linguaria, pod red. V. Mitrinović, Poznań 2001, s. 77-81. Por. też moje uwagi o korekcie w artykule o Bessie i hossie w języku polskim (JP LXXXVII, 2007, s. 161-64, dopisek P. Żmigrodzkiego, tamże, t. LXXXVIII, 2008, s. 89). Zob. też Z. Gałecki, Polacy nie gęsi... europeiści gęsi język mają, „Lamus" [Gorzów Wielkopolski] 2008, nr 1 (17), s. 46-52.

2 Autorka m.in. licznych artykułów poświęconych tej problematyce oraz dwu książek (Angielskie elementy leksykalne w języku polskim, Kraków 1994 oraz Tendencje rozwojowe współczesnych zapożyczeń angielskich w języku polskim, Kraków 1995).

3 Wpływ języka angielskiego na słownictwo polszczyzny ogólnej, „Poradnik Językowy” 2007, nr 5, s. 44-53. 
zapożyczeniami strukturalnymi, najmniej uwagi zaś - jak sądzę - poświęcono zapożyczeniom semantycznym ${ }^{4}$. A zmiany te są równie częste jak zapożyczenia leksykalne, mają długą historię i - dodajmy - nie są bynajmniej typowe wyłącznie dla polszczyzny ${ }^{5}$. Praca Alicji Witalisz „Anglosemantyzmy w języku polskim - ze słownikiem" wypełnia więc ważną lukę w badaniach nad wpływami obcymi w polskiej leksyce, w szczególności zaś nad polsko-angielskimi kontaktami językowymi.

Książka składa się z pięciu części (w tym rachunku pomijamy wstęp, zakończenie i bibliografię, które choć istotne i potrzebne $\mathrm{w}$ strukturze pracy, to przecież nie są najważniejsze). Dwie pierwsze mają charakter teoretyczny i terminologiczny - są wprowadzeniem w zagadnienie rozwoju znaczeniowego wyrazów, zapożyczania znaczeń i kalkowania. Tu autorka omawia starszą i nowszą literaturę przedmiotu, przeważnie zachodnią (anglojęzyczną, niemiecką, francuską). Nie pomija też Witalisz prac badaczy polskich (np. Buttler, Kurkowska, Markowski) oraz rosyjskich (Zwiegincew), choć w nowszej literaturze naukowej w Rosji można by - jak sądzę - znaleźć więcej ciekawych opracowań i ujęć. Nie czynię, a przynajmniej nie mam takiego zamiaru, czynić $z$ tego autorce zarzutu, gdyż nazwiska i prace, które przytacza w swojej książce wystarczają aż nadto. Konstatuję jedynie fakt, że rosyjska literatura przedmiotu jest tu słabo obecna. To jest przykład reorientacji młodszego pokolenia badawczego, dla którego dziś przeważnie ex occidente lux, gdy w nieodległej przeszłości światło było ex Unione Sovietico ${ }^{6}$.

4 Sąd taki sformułowałem, opierając się na lekturze licznych, lecz przecież tylko wybranych, prac normatywnych poświęconych wyrazom zapożyczonym, w artykule Czy wieduszczij jest jeszcze rusycyzmem semantycznym? „Facta Simonidis" 2009, nr 1 (2), s. 205-211.

5 Obszerna literatura przedmiotu u Witalisz (s. 321-339). O neosemantyzmach np. w języku słowackim zob. m.in. O. Humenna, Semantyczni zapozyczennia u łeksyci suczasnoji słowaćkoji mowy (na materiali presy kincia XX - poczatku XXI st.), „Problemy Slovjanoznawstwa" 55, 2005, s. 236-245.

6 Tej opinii nie należy odbierać jako wyrazu lekceważenia względem lingwistyki rosyjskiej (również radzieckiej). W latach sześćdziesiątych i siedemdziesiątych działało w b. ZSRR wielu wybitnych badaczy języka. Niektóre z ich osiągnięć znalazły uznanie $\mathrm{w}$ świecie, inne czekają na odkrycie i upowszechnienie. O sytuacji w lingwistyce w ZSRR interesująco pisze W. Iwanow w książce Lingwistika trietjego tysiaczilietija, Moskwa 2004. Nas szczególnie zainteresują uwagi autora w części pt. Wmiesto priedisłowija, s. 7-8. Z pewna ironią natomiast myślę $\mathrm{w}$ tym momencie o nastawieniu $\mathrm{w}$ środowisku językoznawczym w Polsce, szczególnie o tej jego części, którą Baudouin de Courtenay nazwałby bez ogródek „uczienaja tołpa” (J. N. Baudouin de Courtenay, Niekotoryje obszczije zamieczania o jazykowiedienii i jazykie, [w:] tenże, Dzieła wybrane, t. 4, Warszawa 1990, s. 50, przyp. 1), która dość bezrefleksyjnie przyjmuje niektóre z idei i pomysłów z Zachodu. 
Z bibliograficznych braków wspomnieć trzeba jednak o kilku jeszcze pracach, nie tyle by autorce wytknąć ich nieznajomość, co ujawnić światu ich istnienie, bo mimo Internetu $\mathrm{z}$ obiegiem informacji naukowej nie jest najlepiej. Mam tu na myśli najpierw książkę A. Otwinowskiej-Kasztelanic "A study of the lexico-semantic and grammatical influence of English on the Polish of the younger generations of Poles (19-35 years of age)" gdzie na s. 34-35 omówiono badania nad zapożyczeniami semantycznymi, a cały rozdział 6 (s. 84-99) poświęcony jest ich analizie. O zapożyczeniach semantycznych wspomina Otwinowska-Kasztelanic również $\mathrm{w}$ innych miejscach swojej pracy (zob. s. 128, 150-151). Drugą pracą jest książka K. Nettmann-Multanowskiej „English Loanwords in Polish and German after 1945: Orthography and Morphology", w szczególności zaś rozdział 4 pt. „The borrowing process: Selected terminology” (s. 57-72). Wreszcie trzecia, nieznana mi osobiście, opublikowana tylko w Internecie praca A. Hammert „Zmiany w użyciu anglicyzmów w języku polskim na przestrzeni ostatnich 15 lat. Analiza czasopisma „Twój Styl” z lat 1990, 1991, 2005 i 2006"8, gdzie również wspomina się o zapożyczeniach semantycznych.

W rozdziale pierwszym pt. „Neosemantyzmy i mechanizmy zmian semantycznych" (s. 23-66) autorka tłumaczy najpierw, czym jest neosemantyzm i jakie są jego funkcje, przedstawia kwestię arbitralności i relatywności znaczeń wyrazów oraz ich strukturę semantyczną. Następnie zaś - jakby wynikało z tytułu - zamierza przedstawić „mechanizmy rozwoju semantycznego wyrazów". W rzeczywistości jest to raczej (zdaje się, że takie użycie raczej jest w polszczyźnie nowe, czy aby nie szerzy się pod wpływem języka angielskiego, por. ang. rather) „stan badań nad zmianami semantycznymi" (punkt 1.5, s. 34-66). Autorka sięga tu aż do starożytności (s. 34), ale dokładniej omawia jedynie teorie zmian semantycznych kilku badaczy z przeszłości nie tak odległej (H. Paula, K. Jaberga, G. Sterna i S. Ullmana).

W rozdziale drugim pt. „Zapożyczenia semantyczne i kalki strukturalne jako wynik przeniesienia znaczenia i substytucji morfemowych" (s. 67-120) „,autorka analizuje zapożyczenia semantyczne, tj. neosemantyzmy, których nowe znaczenia powstały pod wpływem obcym oraz kalki strukturalne" (s. 18). Omówione tu zostają problemy z definicją zakresu

\footnotetext{
7 Warszawa 2000.

8 Norderstedt 2007. Por. http://www.hausarbeiten.de/faecher/vorschau/86388.html.
} 
badań nad zapożyczeniami semantycznymi, ich historia, kwestia odróżnienia zapożyczeń semantycznych od homonimicznych wobec istniejących zapożyczeń leksykalnych. Autorka analizuje także kryteria rozróżniania, czy rozwój semantyczny wyrazu jest wynikiem wewnętrznej ewolucji wyrazu, czy zmianą pod wpływem języków obcych.

Najważniejszy w pracy jest rozdział trzeci pt. „Anglosemantyzmy w języku polskim" (s. 121-191). Nieco wbrew tytułowi omawia tu autorka także inne zagadnienia, m.in. kryteria ustalania źródła anglosemantyzmów, definiuje pojęcie anglosemantyzmu oraz omawia kierunki modyfikacji znaczeniowych zapożyczeń semantycznych. Znaczną część rozdziału zajmuje "przykładowa analiza pochodzenia oraz zmiany semantycznej anglosemantyzmu" (par. 3.4) oraz omówienie wtórnych neologizmów, tj. wyrazów zapożyczonych wcześniej z łaciny, a następnie pod wpływem języka angielskiego zmieniły swoje znaczenie, np. korespondować w nowym znaczeniu 'być w związku z czymś, być stosownym, odpowiadać czemus', gdy dawniej tylko w znaczeniu 'porozumiewać się listownie' (par. 3.5). Następnie autorka omawia kalki strukturalne z języka angielskiego, internacjonalizmy, których źródłem jest język angielski, ,jak anglosemantyzmy wchodzą do języka polskiego" oraz pola tematyczne, w których anglosemantyzmy występują najczęściej. Ze względu na mnogość problemów trudno je w tym miejscu przedstawiać szerzej. Przyjdzie nam więc zająć się tylko tym, co w tej części „Anglosematyzmów” A. Witalisz nietrafne albo co budzi wątpliwości.

1) Omawiając kryteria ustalania źródła anglosemantyzmów na pierwszym miejscu A. Witalisz wymienia kryterium historyczne. W definicji tego kryterium pojawia się jednak błąd logiczny circulus vitiosus. Najpierw autorka pisze, iż wykorzystanie tego kryterium „opierałoby się na zbadaniu literatury przedmiotu dotyczącej zapożyczeń obcych w języku polskim w danym okresie oraz jeśli to możliwe, na przestudiowaniu materiałów źródłowych z danego okresu w poszukiwaniu dowodów w postaci przykładów zapożyczeń. Takie działania pozwoliłyby ustalić, jaki język miał największy wpływ na polszczyznę w danym czasie." (s. 122) Nieco dalej zaś dodaje:

Biorąc pod uwagę historię zapożyczeń $w$ języku polskim oraz wpływy języków obcych na polszczyznę $w$ różnych okresach naszej historii, wyraźnie widać, iż od paru dziesięcioleci, językiem, który wywiera istotny wpływ na współczesną polszczyznę jest język angielski. 
Rodzi się więc - jak sądzę - zasadne pytanie, czy można na podstawie historii zapożyczeń dowodzić, że zapożyczamy z języka angielskiego, gdy jeszcze tej historii nie znamy.

2) Na s. 127 A. Witalisz pisze o kulturowych zapożyczeniach semantycznych. Niewątpliwie sklepy typu Wszystko po 4 złote powstały na wzór takich instytucji $w$ innych krajach. Ale przecież nie jest to zapożyczenie semantyczne, nazwa nie powstała na wzór amer. One Dollar (dodajmy, że możliwe też np. Dollar King i podobne, w Japonii np. $100 ¥$ Shop, jap. 百円ショップ, hyaku en shop). Gdyby taki sklep nazwano Jeden Złoty, mielibyśmy onomastyczną kalkę strukturalną, co do której nie wiem, czy ją zaliczyć do anglosemantyzmów, czy nie (zob. nast. punkt).

3) Do anglosemantyzmów bowiem autorka zaliczyła „zarówno zapożyczenia semantyczne z języka angielskiego [...], jak i kalki strukturalne, zarówno słowotwórcze jak i frazeologiczne, powstałe pod jego wpływem [...]” (s. 134). Gdy jednak już w następnym zdaniu czytam, że „kalk strukturalnych nie traktuje się tu jako neosemantyzmy", to nie wiem, jakie stanowisko przyjmuje autorka.

4) Gdy autorka pisze o „postępującej symplifikacji polszczyzny przejawiającej się w używaniu słów kluczy wyrażających tak zwane 'wszystko i nic', jak np. wyraz fajny" (s. 147), jej pogląd trzeba nazwać nie inaczej, jak zabobonem lingwistycznym. Jak bowiem dowieść, że polszczyzna upraszcza się, uprościła, komplikuje się etc. Zabobony tego typu są dosyć częste nie tylko wśród niefachowców ${ }^{9}$.

5) Czy są jakieś dowody, że Mączyński i Knapski świadomie pomijali zapożyczenia leksykalne (s. 154)?

6) Na s. 166 używa autorka pojęcia „internacjonalizm w sensie funkcjonalnym". Przykładem takiego internacjonalizmu jest $\mathrm{w}$ książce przysłówek dokładnie w nowym znaczeniu, odpowiadającym ang. exactly. Jeśli niem. ja, genau czy fr. exactement również powstały pod wpływem angielskim, to mamy tu raczej rozwój paralelny, bo internacjonalizmy - jak to autorka dalej definiuje - to wyrazy występujące w różnych językach,

9 Przykładem takiego zabobonnego myślenia w lingwistyce może być art. K. Mosiołek-Kłosińskiej, Poproszę o pasztet z babuni, „Wiedza i Życie” nr 12, 1997 (http://archiwum.wiz.pl/1997/97124900.asp), w którym utrzymuje autorka, że polszczyzna "uprościła się przez ostatnie wieki". Długą listę takich lingwistycznych zabobonów znajdziemy w książce Language myths, ed. by L. Bauer and P. Trudgill, London 1998. Czy do tej samej kategorii zaliczyć stwierdzenie o językach indoeuropejskich, które są wręcz "skazane" na powstawanie w nich przenośni (s. 61), co A. Witalisz podaje za Bréalem (Essai de Sémantique, Paris 1897, s. 3)? Co na takie dictum powiedzą kognitywiści? 
które „oparte są na wspólnym rdzeniu” (s. 167) ${ }^{10}$.

W rozdziale czwartym pt. „Ocena normatywna omawianych zjawisk” (s. 193-208) A. Witalisz przedstawia krótko kryteria poprawności językowej, pojęcie błędu językowego oraz stanowisko językoznawców polskich wobec obcych elementów w języku. Najistotniejszą część rozdziału stanowi jednak paragraf 4.3, w którym autorka dzieli anglosemantyzmy na uzasadnione i zbędne, do tych pierwszych zaliczając te, które pełnią funkcję nominatywną, tj. „nieposiadające odpowiedników w języku polskim, zwykle wypełniających lukę $\mathrm{w}$ polskim systemie semantycznym, np. nazywając najnowsze wytwory techniki" (s. 197). Do zbędnych neosemantyzmów natomiast autorka zalicza anglosemantyzmy „o funkcji ekspresywnej, tj. takie nowe znaczenia, które jako bardziej atrakcyjne i przykuwające uwagę odbiorcy, zostają wprowadzone do współczesnej polszczyzny w miejsce istniejących już polskich odpowiedników" (tamże). Takie stanowisko nie wydaje się zasadne. Samo bowiem użycie starego, rodzimego bądź zapożyczonego dawniej wyrazu, w nowym, obcym znaczeniu tylko $\mathrm{w}$ funkcji ekspresywnej, nie jest jeszcze naganne. Negatywną ocenę normatywną otrzyma dopiero wtedy, gdy środki ekspresji językowej nie są odpowiednie do sytuacji i kontekstu, gdy są stosowane bez umiaru, gdy stają się manierą. Gdy zaś mowa o elementach obcych w funkcji nominatywnej, to ocenimy je negatywnie także, jeśli są objawem snobizmu, jeśli dowodzą nieznajomości języków obcych. Z takich to powodów, nie odważyłbym się zaliczyć automatycznie każdego nowego anglosemantyzmu w funkcji ekspresywnej tylko do elementów w języku zbędnych. Również zaliczenie anglosemantyzmów o funkcji nominatywnej do uzasadnionych nie może się odbywać automatycznie. Istnieją przecież różne sposoby tworzenia nowych słów, trzeba tylko wiedzieć, jak z nich skorzystać11.

10 Fr. exactement ma ten sam rdzeń, co angielskie exactly, ale tu wspólność rdzenia ma źródło historyczne, nie jest to więc powód, by mówić o internacjonalizmie.

11 W bibliografii brakuje mi wyraźnie artykułu A. Gawrońskiego O podstawie psychologicznej zapożyczania wyrazów obcych, "Język Polski" VI, 1921, s. 1-8, 46-55, 73-78. Przedruk w: tenże, Szkice językoznawcze, Kraków 1928, s. 51-83. Przedstawiona przez Gawrońskiego analiza przyczyn zapożyczania wyrazów obcych o funkcji nominatywnej i o funkcji ekspresywnej (autor stosuje nieco inna terminologię), jawi się zaskakująco nowocześnie. Gawroński jest jednak jak najdalszy od potępienia zapożyczeń o funkcji jedynie ekspresywnej. Zob. tenże, Szkice..., s. 69 i nast. Przy okazji zwróćmy uwagę, że neologizmy jako sposób ucieczki od zapożyczeń nie zawsze są udane. Tak jest np. ze słowem samochód, które dla A. Witalisz jest przykładem udanego zastąpienia wyrazu obcego rodzimym (s. 206). Naszym zdaniem - nie. Samochód jest tworem nieudanym (oczekiwalibyśmy *samojazdu), ale zgodnym z uzusem. A. Gawroński: „nieświetny zresztą neologizm” (op. cit., s. 72). 
Część piątą książki stanowi poprzedzony krótkim wstępem „Słownik anglosemantyzmów" (s. 213-303). Obejmuje on około 300 jednostek leksykalnych, które $\mathrm{w}$ ostatnim czasie zmieniły swoje znaczenie pod wpływem jezzyka angielskiego. Materiał ten pochodzi ze współczesnych tekstów. Znalazły się $w$ nim również leksemy z kwalifikatorem $O$. tj. okazjonalizmy. Nie ma $w$ nim natomiast miejsca na słownictwo ściśle specjalistyczne, żargony zawodowe (nazwane przez autorkę „profesjolektami”, s. 215) i niektórych grup wyrazów, których zaliczenie do grupy anglosemantyzmów wydaje się problematyczne. Założenia słownika są dobre. Wątpliwości budzi opracowanie niektórych haseł oraz zasady stosowania kwalifikatora okazjonalizm. Opatruje nim bowiem autorka anglosemantyzmy „nienotowane jeszcze w słownikach języka polskiego, które być może ulegną kiedyś upowszechnieniu" (s. 217) ${ }^{12}$. To prowadzi do paradoksu - wyrazy od dawna upowszechnione, piętnowane $\mathrm{w}$ wydawnictwach normatywnych za zbyt częste używanie trafiają na listę okazjonalizmów, gdyż nie znalazły się w najnowszych słownikach, często właśnie ze względu na normatywne założenia słowników ${ }^{13}$. Przykładowo, kwalifikatorem O. autorka oznacza hasło absolutnie, pierwsze w słowniku (s. 218). Absolutnie $\mathrm{w}$ nowych, zapożyczonych $\mathrm{z}$ angielskiego znaczeniach 1 . ' $\mathrm{z}$ całą pewnością, na pewno' i 2. 'oczywiście' nie można zaliczyć do okazjonalizmów ze względu na jego rozpowszechnienie. Przecież, o czym autorka wie, już w 1992 r. pisał o tym wyrazie A. Markowski ${ }^{14}$, co dowodzi, że to nowe znaczenie ustabilizowało się, przynajmniej $w$ niestandardowych czy nieoficjalnych odmianach polszczyzny. Podobnie $\mathrm{z}$ hasłem anatomia 'szczegółowy opis czegoś, anatomia' (s. 224). Jeśli anatomia w tym znaczeniu "w pol. od pocz. lat 1980-tych być może za ang. anatomy", nie jest okazjonalizmem, nawet jeśli $\mathrm{z}$ różnych powodów nie została odnotowana w słownikach języka polskiego.

Zdaniem recenzenta $\mathrm{w}$ słowniku powinny znaleźć się też niektóre wyrazy bardzo popularne, takie jak np. biblia (częste w wyrażeniach typu biblia witamin, biblia zdrowia, etc.), komórka (telefon mobilny?) ${ }^{15}$, pakiet 'bro-

$12 \mathrm{~W}$ cytatach z pracy A. Witalisz zachowuję wszelkie właściwości językowe autorki recenzowanej książki.

13 Por. T. Piotrowski, Z zagadnień leksykografii. Warszawa 1994, s. 59-62.

14 Najnowsze anglicyzmy semantyczne w polszczyźnie, Poradnik Językowy 1992, z. 4, s. $156-160$.

15 Komórka $\leftarrow$ telefon komórkowy, co od ang. cell(ular) phone. W 1947 r. inżynierowie z Bell Labs zaprojektowali sieć stacji nadawczo-odbiorczych dla telefonii mobilnej. Stacje miały 
szura informacyjna, folder' ${ }^{16}$. Możliwe, że ich szerokie rozpowszechnienie sprawia, że przestajemy postrzegać je jako neosemantyzmy. Powinny się też znaleźć w słowniku neosemantyzmy omówione w książce (np. świe$\dot{z} y$, s. 144).

Sporo zastrzeżeń budzi opracowanie niektórych haseł. Przykładowo, faktor w nowym znaczeniu 'współczynnik określający stopień pochłaniania promieni ultrafioletowych w filtrach ochronnych' nie jest - jak sądzę - zapożyczeniem semantycznym, lecz zwykłym zapożyczeniem leksykalnym, homonimicznym wobec zapomnianego już faktora w jednym ze znaczeń 1. 'pośrednik, stręczyciel', 2. 'czynnik', 3. 'pełnomocnik', 4. 'listonosz'. Na s. 252 autorka źle definiuje katalog: 'uporządkowany zbiór plików komputerowych; plik' Katalog to ani nie 'uporządkowany zbiór plików komputerowych', ani nie 'plik'. W systemach komputerowych przestrzeń na dysku dzieli się na mniejsze części o hierarchicznej strukturze, które służą do przechowywania plików. W ostatnim czasie, szczególnie w systemach operacyjnych z firmy Microsoft, nazwę katalog zastępuje się nazwą folder 'teczka, przegródka na pliki' ${ }^{17}$. Plikiem natomiast albo zbiorem nazywa się pewną porcję danych zapisanych w odpowiedni sposób, zwany formatem. Przykład, który ma ilustrować hasło katalog, jest dobrany źle. Występuje w nim bowiem wyrażenie katalog komputerowy, a tu o nowym znaczeniu nie ma mowy. Katalog komputerowy to przecież 'wykaz, spis przedmiotów, najczęściej książek (niekiedy także osób)', tyle że $\mathrm{w}$ innej postaci fizycznej niż tradycyjny biblioteczny rejestr książek (stąd przydawka komputerowy), tu po prostu stare słowo przeniesiono na nową rzecz, niekoniecznie pod wpływem angielskim (por. polskie pióro i pióro wieczne). A już z pewnością katalog komputerowy nie pasuje do definicji znaczenia wyrazu katalog.

Przedstawiony powyżej, z konieczności dość powierzchowny, przegląd zawartości książki „Anglosemantyzmy w języku polskim - ze słownikiem" dowodzi, że praca a Witalisz to rzecz ważna, pionierska, przed-

być umieszczone w narożnikach sześcioboków. Każda stacja miała nadawać sygnał w trzy strony na obszar sąsiedniego sześcioboku. Każdy z sąsiadujących sześcioboków nazwano wtedy komórką (ang. cell). My proponujemy nazwać telefony komórkowe telefonami miodowymi ( ${ }^{*}$ miodkami), bo obszar zasięgu sieci przypominałby z góry plaster miodu.

$16 \mathrm{~W}$ tym znaczeniu pakiet (informacyjny) rozpowszechniony $\mathrm{w}$ środowisku uniwersyteckim. Obśmiałem w felietonie pt. Tobołek informacyjny opublikowanym w „Forum Akademickim" (1999, nr 4, s. 60).

17 Folder w tym znaczeniu też jest angielskim neosemantyzmem, choć przez A. Witalisz nie został dostrzeżony. 
stawiająca zagadnienie wpływu języka angielskiego na rozwój semantyczny wyrazów polskich w sposób kompleksowy. Paradoksalnie, to co stanowi o wartości pracy, jest też źródłem jej słabości. Powodów można wskazać kilka.

1) Wydaje się, że autorka zbyt wiele uwagi poświęca historii badań nad zapożyczeniami (zresztą, nie tylko zapożyczeniami semantycznymi). W odpowiednich częściach książki (przede wszystkim w rozdziale 1. i 2.) roi się od nazwisk, koncepcji, klasyfikacji a przede wszystkim terminów, nad którymi trudno zapanować, co zresztą i autorce nie zawsze się udaje, np. na s. 58 czytamy: „Ullmann twierdził, że na jego system klasyfikacji zmian znaczeniowych wpłynęła praca Roudeta (1921), która według Ullmanna była lepszą wersją [sic!] klasyfikacji Sterna (1931)"; czy Paul mógł podążać „śladem Saussure'owskiej teorii języka" (s. 41), jeśli jego Prinzipien der Sprachgeschichte ukazały się po raz pierwszy w 1880 r., na długo przed kursem językoznawstwa ogólnego F. de Saussure'a ${ }^{18}$. Co ważniejsze, większość przywołanych koncepcji i dystynkcji terminologicznych nie przydaje się potem do analizy materiału. To niepotrzebna drobiazgowość. Tematem pracy są anglosemantyzmy w języku polskim, a nie dzieje badań nad neosemantyzmami czy analiza terminologii lingwistycznej.

2) W związku z powyższym pojawia się dysproporcja. Stan badań, bo w gruncie rzeczy tak trzeba nazwać pierwszy i drugi rozdział pracy, dominuje nad samą analizą materiału językowego (dziś powiedzielibyśmy danych językowych, ale to chyba neosemantyzm albo kalka strukturalna, por. ang. linguistic data). Nic by pracy nie zaszkodziło, gdyby autorka w większej mierze skupiła się na gromadzeniu materiału lingwistycznego i jego analizie, miast grzebać się w terminologicznych zawiłościach.

3) W książce przydałby się indeks wyrazów. To oczywiście zarzut do wydawcy. Anglosemantyzmy, nie tylko polskie, omawiane są bowiem we wszystkich rozdziałach książki, wśród nich są takie, których nie ma w słowniku. Z zasady zaś nie ma w słowniku wyrazów obcych licznie

18 Prinzipien der Sprachgeschichte Hermana Pola wymienione są wśród książek, które ukształtowały światopogląd lingwistyczny M. Kruszewskiego, kazańskiego prekursora strukturalizmu, ucznia Baudouina de Courtenay. Rodzi się więc pytanie, czy to Paul podążał śladem de Saussure, czy de Saussure czerpał z Paula. Podług L. Antala dychotomia langue || parole u de Saussure'a pochodzi od Hermana Paula, a nie odwrotnie. Zob. L. Antal, Some comments on the relationship between Paul and Saussure, "Cahiers Ferdinand de Saussure" 35, 1985, s. 121. Antal idzie tu za pracami E. F. K. Koernera Herman Paul and synchronic linguistics („Lingua” 29, 1972, s. 274-307) oraz Ferdinand de Saussure. Origins and development of his linguistic thought in Western studies of language, Braunschweig 1973. 
przytaczanych $\mathrm{w}$ wywodach autorki. Z książek takich, jak tu omawiana, korzysta się niejednokrotnie tak, jak $\mathrm{z}$ baz danych, tj. poszukuje się $\mathrm{w}$ nich omówionych wyrazów i zwrotów. Bez indeksu jest to niemożliwe. Indeks prawdopodobnie wykazałby też, że niektóre przykłady powtarzają się w książce po kilka razy, jakby autorce brakowało materiału ilustracyjnego. Kilkakrotnie w książce pojawia się agresywny, m.in. s. 52, bank (krwi etc.), m.in. s. 27, 44-45, obszar, m.in. s. 90, 102, 186, 202, Pierwsza Dama, m.in. na s. 23, 103, 161, 168, o której w następnym punkcie z innego jeszcze powodu.

4) Wśród przykładów powtarzają się wyrażenia typu pierwsza dama. Autorka dość konsekwentnie używa w ich pisowni wielkiej litery (Pierwsza Dama, Gabinet Cieni). Czy aby zasadnie? To chyba też wpływ języka angielskiego.

Jak napisałem na początku, książka A. Witalisz wypełnia lukę w badaniach nad zapożyczeniami leksykalnymi w języku polskim. Przynosi interesujący materiał, który został poddany wnikliwej analizie. Autorka omówiła także obszerną literaturę przedmiotu. Wszystko to stanowi o wartości pracy. Nie ustrzegła się jednak i różnego rodzaju błędów. Część z nich omówiłem wcześniej, przy okazji przedstawiania zawartości pracy. O innych - drobniejszych, lecz przecież istotnych - wspominam dalej. Najkrócej mówiąc - dobrze dobrany, społecznie ważny temat, dobra znajomość literatury przedmiotu, ale niepotrzebna dysproporcja miedzy teorią a analizą samego materiału i sporo niedociągnięć w szczegółach. W zakończeniach recenzji piszą zwykle, że wykazane błędy i usterki nie ujmują wartości pracy. To oczywiście eufemizm, bo przecież ujmują, a gdyby było inaczej, nie warto by o nich wspominać. Bez wykazanych przeze mnie błędów i usterek praca A. Witalisz, choć dobra, nowatorska i potrzebna, mogłaby być jeszcze lepsza.

Na koniec muszę zwrócić autorce uwagę na dość niestaranny język publikacji. Kwestie techniczne, np. znaki interpunkcyjne etc., pomijam, bo wszyscy wiemy, jak dziś wygląda proces przygotowania prac naukowych do druku. Myślę tu natomiast o wyrażeniach z języka potocznego i biurokratycznego, np. na etapie (s. 127, 176), na obecnym etapie (s. 167) ${ }^{19}$, na przestrzeni wieków (s. 29, 109, 113) ${ }^{20}$, natrętne ostatnio w sensie (s. 24,

19 Wielki słownik poprawnej polszczyzny PWN, pod red. A. Markowskiego (wyd. I, Warszawa 2007, s. 246-247) ostrzega: „nadużywane w połączeniu Na etapie czegoś, lepiej: w trakcie, w czasie, w okresie czegoś". Starszym trąci PRL-em.

20 Lepiej: $w$ ciagu, podczas. Tamże, s. 907. 
27, 89, 90, 200 - czy aby nie zapożyczenie semantyczne), forma anglosemantyźmie zamiast zgodnej z normą anglosemantyzmie (s. 199) ${ }^{21}$, poprawność językowa produktów opisywanych zjawisk (s. 193) z rzeczownikiem produkt $\mathrm{w}$ nowym zapożyczonym, ale chyba jeszcze nie ustalonym znaczeniu ${ }^{22}$, zapożyczenia intymne, co jest chyba oczywistym zapożyczeniem semantycznym (tu dosłownym przekładem, bo w nawiasie autorka podaje angielski odpowiednik).

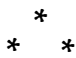

Tadeusz Brajerski, mój lubelski mistrz i nauczyciel, opowiadał przed laty, jak to, otworzywszy jeden z tomów tzw. „żółtej” gramatyki²3, przeczytał początek któregoś $\mathrm{z}$ rozdziałów i ze zdumieniem odkrył, że $\mathrm{w}$ pierwszym zdaniu tylko jeden wyraz był polski - spójnik $i$. Dziś jak pokazuje A. Witalisz w omówionej przez nas książce - stajemy wobec innego problemu. Współcześnie bowiem nawet jeśli wyrazy są rodzime, to często występują w nowym zapożyczonym znaczeniu. Książka Witalisz, pionierska w zakresie podejmowanej problematyki spełni swoją rolę, jeśli uczuli nas na ten aspekt wpływu języka angielskiego na polszczyznę XXI wieku.

Henryk Duda

KUL, Lublin - PWSZ, Zamość

21 „Formy miejscownika lp należy pisać z twardą głoską -z-: romantyzmie; jej wymowa jest miękka, rzadziej twarda [...]". Tamże, s. 1536.

22 W tym znaczeniu 'produkt, usługa' dostrzegłem go już dawno. Zob. H. Duda, Język polski po komunizmie..., s. 71. W słowniku A. Witalisz jedynie w nowym znaczeniu 'towar na sprzedaż', ale w zacytowanym zdaniu z omawianej książki chyba nie chodzi o żadne z tych znaczeń. Tu produkt to tyle co 'wynik, rezultat'.

23 Dla porządku jedynie podaję, że ,żółtą” gramatyką nazywano w nie tak przecież odległej przeszłości Gramatykę współczesnego języka polskiego: składnia-morfologia -fonologia, red. S. Urbańczyk, t. 1-2, Warszawa 1984, t. 3, Kraków 1995. 